\title{
Strategies to suppress internal loads of metals in sediments
}

\author{
Anne M. Hansen ${ }^{1, *}$ \\ ${ }^{1}$ Mexican Institute of Water Technology, 62550 Jiutepec, Morelos, Mexico
}

\begin{abstract}
Sediments may act as secondary sources of pollutants, but no known criteria establish such relationship. This study aims at evaluating internal loads of $\mathrm{Ni}$ from sediments due to changing redox conditions caused by application of water treatment such as hypolimnetic oxygenation. Through hydrogeochemical modelling and experimental evaluation, the distribution of $\mathrm{Ni}$ was evaluated. Sediment and water samples from a reservoir located in central Mexico were located in a reactor and Eh was controlled in $\pm 50 \mathrm{mV}$ steps between +300 and -450 $\mathrm{mV}$. The release of $\mathrm{Ni}$ was evaluated in each step and the results were construed to the reservoir, considering that water-sediment interaction occurs in a 5-cm sediment layer with known density. Under oxidized conditions, the metal was accumulated in the sediment. With the dissolution of $\mathrm{Fe}$ at lower $\mathrm{Eh}$, dissolved concentrations of $\mathrm{Ni}$ increased. Under even lower Eh conditions, these concentrations decreased again. This was related to the formation of iron sulphide. Combining experimental evaluation with hydrogeochemical modelling, allowed evaluating different scenarios of distribution of $\mathrm{Ni}$. The knowledge of reductive dissolution of metals is therefore essential for decision-making to mitigate health effects as result of water treatment strategies.
\end{abstract}

\section{Introduction}

Water bodies are vulnerable to pollution due to human activities in their hydrological basins. External loads of pollutants can lead to anaerobic conditions in deeper part of water bodies, stimulating the release of contaminants from bottom sediments, or internal load, which reinforces the impact of the external loads. The objective of this study was to generate knowledge focused on the development of strategies to control internal loads of pollutants in water bodies through an evaluation of strategies to suppress internal loads of pollutants from the sediment of a reservoir that supplies water for human consumption. The application of oxygenation will change the anaerobic conditions that currently occur in deeper lakes and reservoirs, especially during periods of thermal stratification, oxidizing metals such as iron and manganese, thus allowing the formation of adsorbing substrates for metals, nutrients and other pollutants, and thereby controlling internal loads. At the same time, a more efficient degradation of organic matter present in water and sediment is

\footnotetext{
*Corresponding author: ahansen@tlaloc.imta.mx
} 
achieved; this probably causes release of accumulated contaminants, producing a redistribution, which must be evaluated.

This study aims at evaluating the internal loads of pollutants at the water-sediment interface due to the effect of changing redox conditions, in order to assess the redistribution of pollutants and the risk of contaminating water. The generated results will serve for a correct decision-making in the strategies for remediation of lakes and dams using oxygenation. Likewise, it will generate scientific knowledge about the processes of redistribution of pollutants by changing redox conditions and will allow providing anticipated solutions to pollution problems that could arise in water bodies due to the effect of remediation actions.

It is expected that the addition of oxygen to the water-sediment interface inhibit the release of metals from sediment through a series of biogeochemical mechanisms, including sorption to organic matter or mineralogical phases in the sediment surface $[1,2]$, oxidation of reduced pollutants by aerobic microbes in the surface sediment [3], and inhibition of sulfate-reducing bacteria in the surface sediment, which are responsible for the production of metal sulphides in anaerobic sediment [4].

\section{Methods}

This study includes a hydrogeochemical modelling and an experimental evaluation of strategies to control the internal loads of metals from sediments through changes in redox potential at the water-sediment interface (Fig. 1).

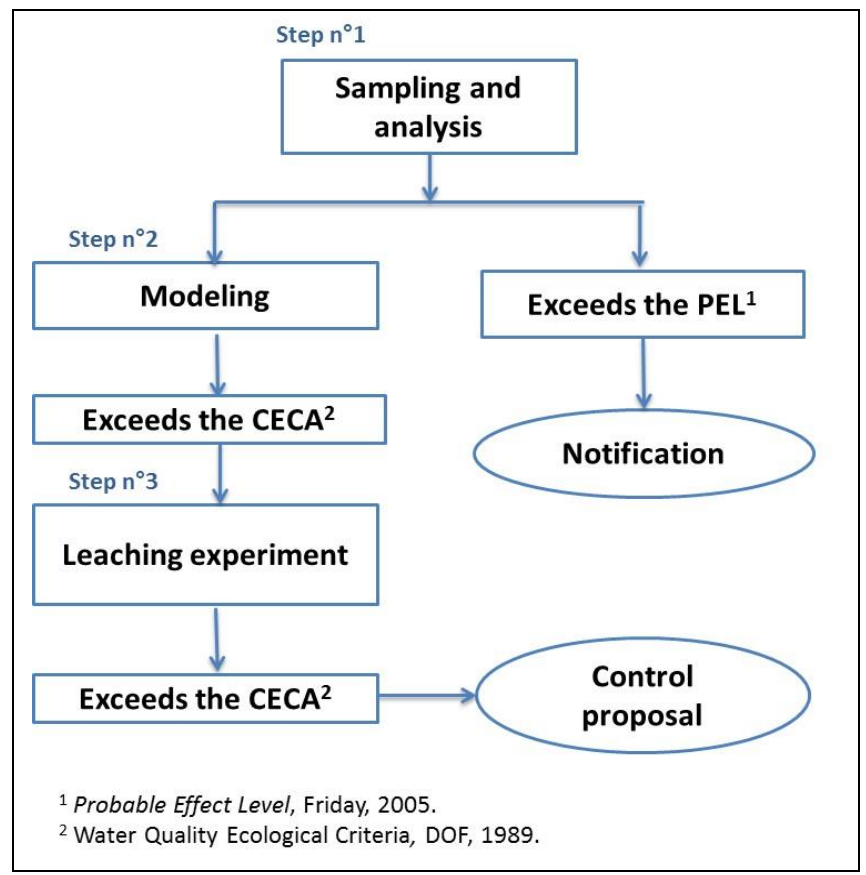

Fig. 1. Procedure to estimate risks of polluting water due to leaching of metals accumulated in sediments. 
Water and sediment samples were obtained from a reservoir located in central Mexico, metal concentrations were determined by inductively coupled plasma atomic emission spectroscopy [5], and compared to effects levels previously reported [6, 7]. Hydrogeochemical modelling was performed to evaluate the redistribution of $\mathrm{Cd}, \mathrm{Cu}, \mathrm{Cr}$, $\mathrm{Fe}, \mathrm{Mn}, \mathrm{Ni}, \mathrm{Ag}$, and $\mathrm{Zn}$ under varying redox conditions using PHREEQC V. 3 [8]. Results were construed considering that sediment interaction with water occurs in a 5 -cm sediment layer with a density of $340 \mathrm{~g} / \mathrm{L}$, and compared to Mexican water quality criteria (WQC) [9]. Concentrations of major ions in aqueous phase were those previously reported [10]. The adsorbing surface of ferrihydrite $(\mathrm{FeOOH})$ and manganese dioxide $\left(\mathrm{MnO}_{2}\right)$ were considered as $10 \%$ of the total concentrations of $\mathrm{Fe}$ and adsorption constants were those given in [11].

The simulated metal distribution scenarios as a function of Eh under different reservoir depth scenarios consider initially the whole amount of trace metals as dissolved and $\mathrm{Fe}$ in the form of $\mathrm{FeOOH}$. Simulations were carried out for $\mathrm{pH} 7.5$ and Eh between -355 and $+355 \mathrm{mV}$ (i.e. pe between -6 and 6), and for each value of Eh the distribution of metals between the dissolved and adsorbed phases was calculated. Metals for which resulting dissolved concentrations exceeded Water Quality Criteria (WQC) were selected for experimental assessment of leaching as function of redox potential. The leaching experiment was performed in a reactor with sediments and water from the reservoir, in the dark and at room temperature of $25+2{ }^{\circ} \mathrm{C}$. Eh was controlled in $\pm 50 \mathrm{mV}$ steps from +300 to $-450 \mathrm{mV}$ and metals leaching was evaluated after equilibration times of two days. Aerobic conditions were obtained by air supply and anaerobic conditions by $\mathrm{N}_{2}(\mathrm{~g})$ supply in the reactor. Additionally, $\left(\mathrm{NH}_{4}\right)_{2} \mathrm{SO}_{4}, \mathrm{KH}_{2} \mathrm{PO}_{4}$, and saccharose were added to achieve lower Eh values in the reactors. Resulting metal concentrations were construed to the above-mentioned water-sediment relation, and compared to WQC [9].

\section{Results and discussion}

The hydrogeochemical modeling of release of $\mathrm{Cd}, \mathrm{Cu}, \mathrm{Cr}, \mathrm{Fe}, \mathrm{Mn}, \mathrm{Ni}, \mathrm{Ag}$, and $\mathrm{Zn}$ from sediment show increases in dissolved metal concentration as Eh decreases, as illustrated for Ni in Fig. 2.

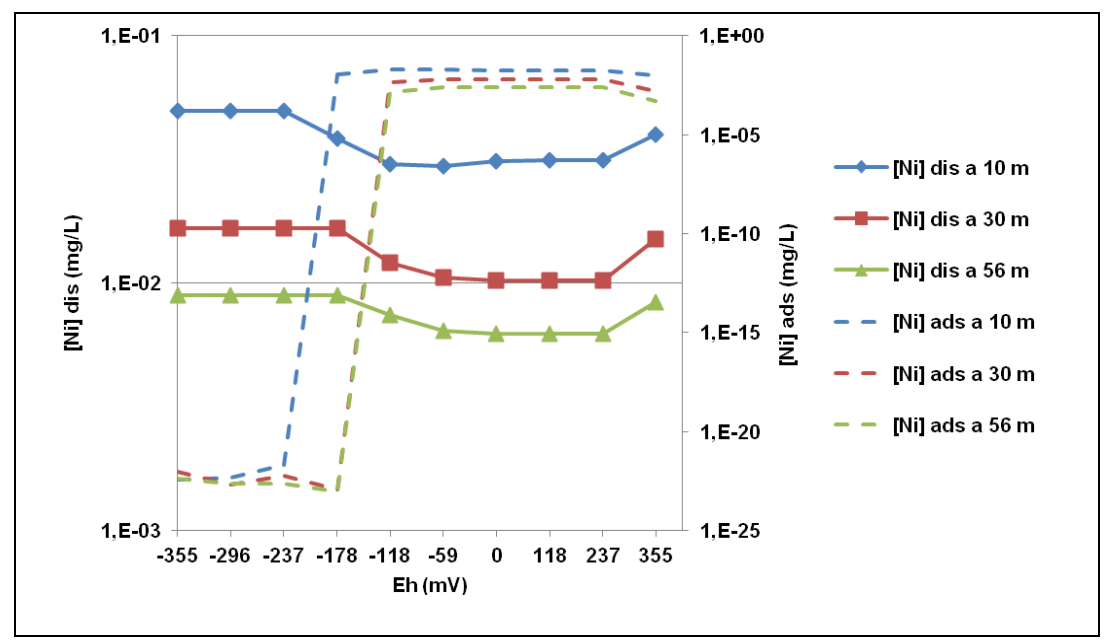

Fig. 2. Hydrogeochemical modelling of the redistribution of $\mathrm{Ni}$ between water and sediment from a reservoir located in central Mexico. Modeling conditions are: $\mathrm{pH}=7.5 . \mathrm{FeOOH}]=0.2 \mathrm{~mole}$, and $[\mathrm{Ni}]=$ $1.52,2.83$, and $8.4910^{-7} \mathrm{M}$ for water depths of 56,30 , and $10 \mathrm{~m}$, respectively. 
After comparing the results to the water-sediment relation expected in the reservoir, only $\mathrm{Ni}$ exceeded the WQC of $0.01 \mathrm{mg} / \mathrm{L}$ and therefore was selected for experimental evaluation.

Experimental results for this metal also show increase in dissolved concentration as Eh decreases (Fig. 3), although as Eh is reduced below $-214 \mathrm{mV}$, dissolved concentrations decrease. The difference between the experimental and modeling results may be explained by the addition of $\left(\mathrm{NH}_{4}\right)_{2} \mathrm{SO}_{4}$ as an energy source to decrease experimental Eh. At Eh of approximately $-214 \mathrm{mV}$, sulfate is reduced to sulphide, forming mackinawite (FeS) and pyrite $\left(\mathrm{FeS}_{2}\right)$ that may remove $\mathrm{Ni}$, causing the observed decrease in dissolved concentrations.

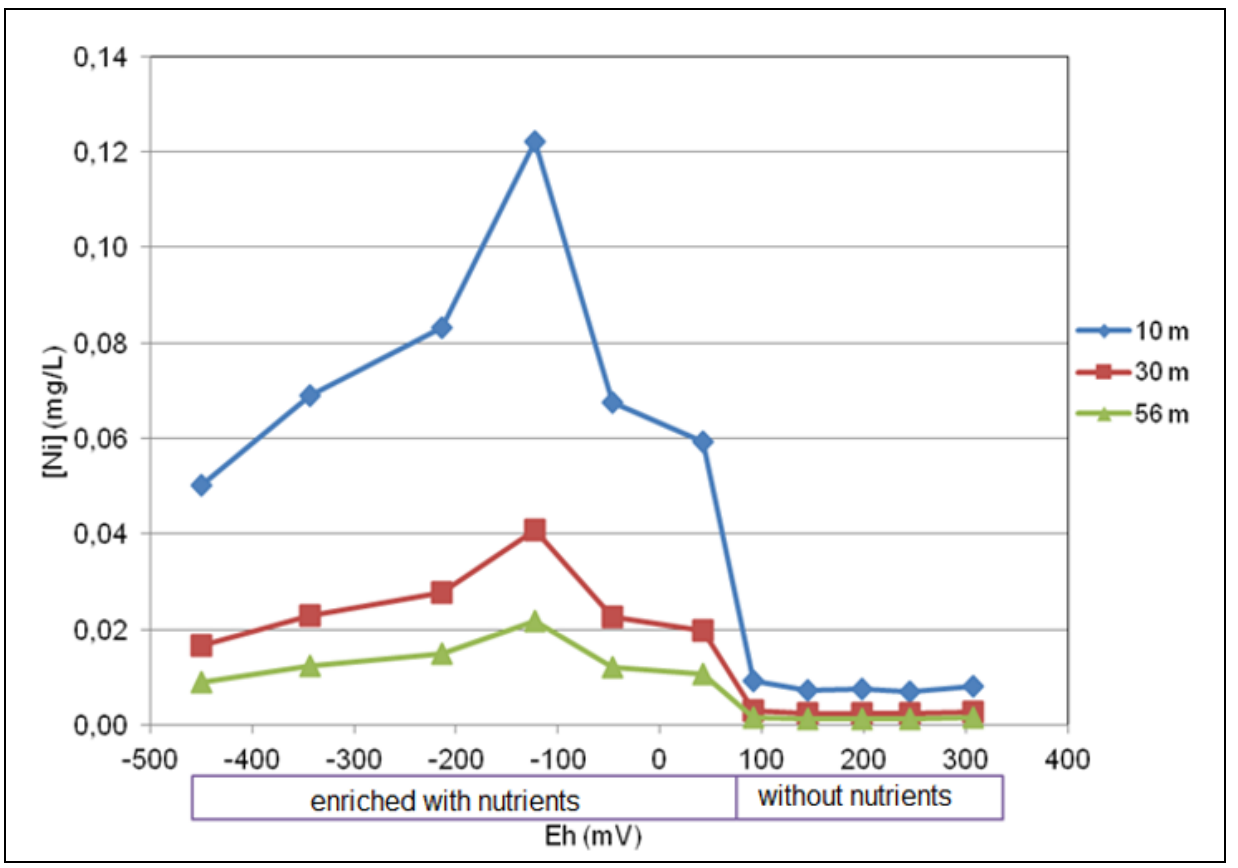

Fig. 3. Experimental results of the redistribution of Ni between water and sediment from a reservoir located in central Mexico. Modeling conditions are: $\mathrm{pH}=7.5,[\mathrm{FeOOH}]=0.2$ mole, and $[\mathrm{Ni}]=1.52$, 2.83 , and $8.4910^{-7} \mathrm{M}$ for water depths of 56,30 , and $10 \mathrm{~m}$, respectively.

The effect of natural and enriched sulfate concentrations on the distribution of Fe were analyzed by [12], demonstrating that Fe may precipitate under nutrient-enriched conditions, whereas this did not occur in the presence of sulfate concentrations measured in the field. The decrease in Eh causes the reductive dissolution of $\mathrm{Fe}(\mathrm{III})$, forming $\mathrm{Fe}^{2+}$ that is soluble. However, when the sulfate added to the system is reduced to sulphide, it reacts with dissolved $\mathrm{Fe}$ to form the solids $\mathrm{FeS}$ and $\mathrm{FeS}_{2}$ as new substrates that may retain metals the divalent metal [13]. This process may explain the decrease in dissolved $\mathrm{Fe}$ and $\mathrm{Ni}$ concentrations at lower Eh observed in the experiments. Such reduction in dissolved metals concentrations may be also be expected in water bodies located in industrial or volcanic areas where higher concentrations of sulfur may be found. 


\section{Conclusions}

The combination of experimental evaluation and hydrogeochemical modeling allows assessing different scenarios of water pollution in contact with sediments.

These results show the importance to understand the reductive dissolution processes and other geochemical reactions where contaminants participate, in mitigating health effects and to making proper decisions on needs for water treatment in lakes and reservoirs.

\section{References}

1. I. Schauser, et al., Acta Hydrochim Hydrobiol, 34, 325-332 (2006)

2. M.W. Beutel, et al., Sci Tot Environ ,496, 688-700 (2014)

3. M.W. Beutel, Ecol Eng, 28, 271-279 (2006)

4. D. Austin, et al., Lake Reserv Mgmt, 32, 61-73 (2016)

5. EPA (US Environmental Protection Agency), Method 6010C (SW-846), Revision 3, (2007)

6. G.P. Friday. Report. Aiken, South Carolina (2005), Available at: https://www.osti.gov/servlets/purl/4764/

7. M.F. Buchman, NOAA OR\&R Report 08-1, Seattle, WA (2008), Available at: https://repository.library.noaa.gov/view/noaa/9327

8. USGS U.S. Geological Survey. PHREEQC, Version 3, (2017) Available at: https://wwwbrr.cr.usgs.gov/projects/GWC_coupled/phreeqc/

9. DOF (Mexican Official Journal of the Federation), (198), Available at: http://www.dof.gob.mx/nota_detalle.php?codigo=4837548\&fecha=13/12/1989

10. A.M. Hansen, L.C. González-Márquez, J Environ Sci Heal A, 45, 99-106, (2010)

11. D.A. Dzombak, F.M.M. Morel. Surface Complexation Modeling: Hydrous Ferric Oxide, John Wiley \& Sons, New York, 393 pp (1990)

12. A.M. Hansen, et al., Rev Int Cont Amb, 29, 179-190 (2013)

13. J.W. Morse, T. Arakaki. Geochim Cosmochim Acta, 57, 3635-3640 (1993) 